\title{
The salt licking activity of the European Moose (Alces alces Linnaeus, 1758) in the Leningrad region of Russia: temporal and behavioral aspects
}

\begin{abstract}
Nickolai V. Sedikhin
ABSTRACT. Long-term monitoring (2015-2019) was carried out on artificial salt licks (a total of 19 in 3 districts). The total monitoring time was 7123 camera trap days. Depending on the place and year of monitoring, from 5 to 33 different individuals were recorded on each salt lick. Six sex and age groups were identified: adult males, yearling males, adult single females, yearling female, adult females with calves, adult females with yearling individuals. All duration data by sex and age groups including "passing" visits have the form of an exponential distribution $\left(\lambda=0.029 \pm 0.001 \mathrm{~min}^{-1}\right)$. The data of the duration of geophagous visits have the form of a gamma distribution $(k=1.76 \pm 0.087 ; \theta=21.20 \pm 1.501 \mathrm{~min})$. European Moose visit salt licks all year round, most actively in May-August. The average duration of a visit is close to half an hour for each of the identified groups (33.7 \pm 1.3 min for all groups; clear time of geophagous visit is $33.2 \pm 2.8 \mathrm{~min})$. The duration of salt licking and the mineral lick attendance differs between some identified sex-age groups and months. During the days of salt licking, the same individual most often visits the lick several times ( 1 to 5 visits a day ( $\max 11)$, on average $1.48 \pm 0.39$ ). The activity of visiting salt licks during the day has a pronounced tendency to acquire peak values in the twilight post-sunset and pre-dawn periods. The moose use a third of the month $(34.9 \% \pm 20.8 \%$ of month) for salt licking, alternating this with varioustime periods break. Age and sex competition for the use of salt licks was noted.
\end{abstract}

How to cite this article: Sedikhin N.V. 2021. The salt licking activity of the European Moose (Alces alces Linnaeus, 1758) in the Leningrad region of Russia: temporal and behavioral aspects // Russian J. Theriol. Vol.20. No.2. P.158-172. doi: 10.15298/rusjtheriol.20.2.05

KEY WORDS: European Moose, Alces alces, salt lick, camera trap, duration, geophagous activity.

Nickolai.V.Sedikhin [sedoi1995@mail.ru] Zoological Institute, Russian Academy of Sciences, Universitetskaya nab. 1, Saint Petersburg 199034, Russia.

\section{Солонцевание европейского лося (Alces alces Linnaeus, 1758) на территории Ленинградской области России: временные и поведенческие аспекты}

\section{Н.В. Седихин}

РЕЗЮМЕ. Проведен длительный мониторинг (2015-2019 гг.) на искусственных солонцах (19 шт в 3 районах). Общее время наблюдения составило 7123 фотоловушко-суток. В зависимости от места и года наблюдения на каждом солонце регистрировалось от 5 до 33 разных особей. Выделено 6 половозрастных групп: взрослые самцы, полуторагодовалые самцы, взрослые одиночные самки, полуторагодовалые самки, взрослые самки с сеголетками, взрослые самки с годовалыми особями. Все данные о продолжительности посещений по половозрастным группам с учетом "проходных" посещений имеют вид экспоненциального распределения $\left(\lambda=0.029 \pm 0.001 \mathrm{~min}^{-1}\right)$. Данные продолжительности литофагиальных посещений имеют вид гамма-распределения ( $k=1.76 \pm 0.087 ; \theta=21.20 \pm 1.501 \mathrm{~min})$. Лоси посещают солонцы круглый год, наиболее активно в мае-августе. Средняя продолжительность посещения составляет около получаса для каждой из идентифицированных групп (33.7 \pm 1.3 мин для всех групп; чистое время литофагиального посещения составляет $33.2 \pm 2.8$ мин). Продолжительность солонцевания и посещаемость солонцов различается между разными половозрастными группами и по месяцам. В течения дня использования солонца одна и та же особь чаще всего посещает его несколько раз (от 1 до $5(\max 11)$ посещения в день, в среднем $1.48 \pm 0.39)$. Активность посещения солонцов в течение дня имеет ярко выраженную тенденцию приобретать пиковые значения в сумерках после захода солнца и в предрассветные периоды. В среднем отмечается около трети $(34.9 \% \pm 20.8 \%)$ дней месяца, в которые регистрируются посещения с различными по времени перерывами между ними. Отмечена возрастная и половая конкуренция за использование солонцов. 
КЛЮЧЕВЫЕ СЛОВА: лось, Alces alces, солонец, фотоловушка, продолжительность, литофагиальная активность.

\section{Introduction}

Migration activity, the timing of migrations, peculiarities of the distribution of mammals in space are associated with many factors, one of which is the need to maintain a certain level of water-salt metabolism, which is very important for herbivores (Cederlund \& Okarma, 1988; Timmermann \& McNicol, 1988; Bjørneraas et al., 2012). Animals are often deprived of sources of mineral nutrition, which can lead to numerous pathologies that can be diagnosed on fossil material. (Hindelang \& Peterson, 1996; Flueck \& Smith-Flueck, 2008; Leshchinskiy, 2017; Panichev, 2011). An important role for herbivorous of mammoth fauna was played by "landscapes enriched with $\mathrm{Ca}, \mathrm{Mg}, \mathrm{Na}, \mathrm{Co}, \mathrm{Cu}$ and other elements" (Leshchinskiy, 2010: 181). Perennial "animal" mineral licks are marked as areas of large concentrations of remains of large mammals (Haynes, 1985; Bobrowsky et al., 1988), possibly associated with the hunting activities of ancient people or with the natural death of animals in places of concentration. To date, an extremely small amount of natural mineral springs is noted in the North-West of the Russian Federation (Timofeeva, 1974). Modern analogues of such places in the form of artificially man-made salt licks can theoretically reveal patterns of movements and dependences of the biotopical distribution of both modern mammals and extinct representatives of theriofauna. As a rule, modern artificial mineral licks and feeding grounds are organized in order to retain representatives of valuable hunting species in limited areas, thereby minimizing human effort for finding and hunting animals. Information about the location and number of salt licks allows us to state that the studied region is covered with artificial salt licks unevenly, and their number is limited. Under these conditions, it becomes possible to consider and study the attendance of these places of perennial feeding by different species, taking into account biotic, abiotic and anthropogenic factors, and the results of the analysis can be interpreted for other habitats or used in the reconstruction of paleoconditions.

The most abundant modern representative of large herbivores in the Leningrad region is the European Moose (Alces alces Linnaeus, 1758). The species is susceptible to a violation of the acid-base balance during seasonal feed changes (Danilkin, 1999; Panichev, 2011) and it has a number of ecological and ethological features (Boeskorov, 2001). It compensates for the sodium deficiency by eating succulent wetland vegetation and visiting mineral springs and artificial feeding places salt licks. Each artificial salt lick, if properly organized, becomes a particular place of moose concentration at a certain time of the year and, like natural mineral licks, affects the movement and distribution of moose throughout the territory (Risenhoover \& Peterson, 1986; Ayotte et al., 2008; Lavelle et al., 2014). For moose, this type of feeding is an easy way to get the necessary minerals with minimal energy consumption. Even though the moose is the main type of hunting resources and a particularly important economic unit of modern forestry, there is still no reliable information on the attendance of artificial salt licks in the North-West of the Russian Federation by different sex and age groups of moose during the year. Also, there is no information about the behavior of moose and the interaction of different groups of individuals on salt licks. These aspects are fundamental for further study of the biotopical characteristics of the moose population in this region since salt licks are seasonal attraction places. To date, the economic use of animal's populations is based on annual monitoring of the abundance by the Winter Route Counts method and a hunting management project for each of the forest game owners with the simplest analysis and forecasting of population dynamics. The suitability assessment of the territory for different game animals is based on the ranking of forest management materials according to the biotopical features for each of the species. Rational approaches to the economic development of moose populations can be significantly improved by creating spatio-temporal models of habitat use. Studying the specifics of habitats, complexes and combinations of biotopes necessary for moose makes it possible to obtain information for creating a distribution model for different areas and seasons. At the same time, modern GIS contribute to the rapid updating of data, correction and reasonableness of economic activity. For this region such studies have not been carried out yet.

Preliminary studies of the moose geophagy (Sedikhin \& Masaitis, 2018) revealed a variety of behavioral responses that differ between salt licks, age and sex groups of animals, and time periods. The main goal of this research was to describe previously unpublished regional temporal and behavioral aspects of geophagous activity of moose on artificial salt licks. The main tasks of this research were: determination the parameters of the distribution of the sample for different categories of visits; determination the average duration parameters of visits with the confidence interval indication for hypothetically different groups of individuals by sex/age/population status by month; identifying differences in the duration of visits between categories of visits and groups of individuals by month; creating graphic interpretation of daily attendance of salt licks by month; description of the observed behavioral features of salt licking and frequency of visits.

\section{Materials and methods}

\section{Study area}

Leningrad region locates in the North-West of the European part of Russia. The north part of the region belongs to the southern boreal zone of taiga. Most of the 
territory is in the hemiboreal zone of taiga, characterized by the presence of temperate broadleaf and mixed forests (Sennikov, 2005). The vegetation conditions are typical for moose. According to the annual state monitoring data and various professional estimates, at the moment, 17-19 thousand moose live in the territory of the Leningrad region (Panchenko et al., 2020; Committee for the Protection, Control and Regulation of the use of Fauna objects of the Leningrad region, Open data https:// fauna.lenobl.ru/ru/statistic/otkrytye-dannye/ ; accessed 15.02.2021). However, the population density is uneven and varies by restricted forest areas from 0.2 to 1.25 animals $/ \mathrm{km}^{2}$ (Yudin \& Skumatov, 2018; unpublished data). The territory of private and public hunting land is $98.44 \%$ of the total area of municipal districts of the Leningrad region (Committee for the Protection, Control and Regulation of the use of Fauna objects of the Leningrad region, Open data; accessed 15.02.2021). In accordance with federal and regional hunting legislation, forest tenants must create and maintain artificial salt licks, but their number is not regulated. Based on the recommendations of professional game managers, each of the hunting farms, as a rule, creates 1 salt lick per 1000-1500 ha, but this is not always done.

\section{Collecting data}

Photo and video footage of visits were obtained using remote monitoring on artificial salt licks (organization from three to 20 years ago) by installing camera traps on trees in a distance less than $5 \mathrm{~m}$ from salt licking point. The following types of cameras were used: Suntek, Bushnell, Browning, Wild Game Innovations, ScoutGuard. In total, 19 artificial salt licks were examined (eight in the Vsevolozhsky district, three in Tosnensky district, eight in Luzhsky district).

The choice of monitoring sites is explained by the author's desire to cover different geobotanical areas with different densities of moose populations, as well as the possibility of permanent stay in the studied areas in order to maintain and check the cameras for their safety. Also, one of the important reasons for the choice of observation points was the interest in this research of hunting farms, on the territory of which the monitoring was carried out. Employees of the Leningrad Society of Hunters and Fishermen (MOO "LOOiR"), the Lisinsky Educational and Experienced Hunting farm (LUOOH) and the Vsevolozhsk Regional Society of Hunters and Fishermen (OO "VROOiR"), contributed in every way to obtaining information, carried out planned raids to suppress cases of poaching and damage to property, including camera traps.

It was decided to tie monitoring in the biological cycle of moose, or rather to the least studied period: in April moose begin to molt, males grow new antlers, females before calving begin to show intolerance and aggression towards the juveniles of the last year, thereby forcing them to live independently. According to literature data (Knorre, 1959; Timofeeva, 1974; Vereshchagin \& Rusakov, 1979) the moose is inactive in winter and adheres to limited areas. Rigid feed, low temperatures slow down the physiological rhythm of the body, which, in turn with minimization of movement activity, negatively affects the attendance of salt licks. Also, in conditions of heavy precipitation and low temperatures, the efficiency and safety of camera traps decreases, monitoring points become unavailable for monthly inspections. That is why most cameras were installed in April-May and dismantled in October-November, and the data for the winter period are extremely scarce and uninformative.

The following criteria for materials on camera traps were installed: photos of at least three megapixels, in the mode 1-3 pcs per 1-5 minutes break; video, resolution of at least $1280 * 720$, obtained in 10-30 seconds per 4-10 minutes break, or data obtained in hybrid mode, photo ( 1 pcs $)+$ video (10-30 seconds) per 4-10 minutes break. Inspection and maintenance of camera traps were carried out once a month.

\section{Materials}

A total of 32639 photos and 17470 video files were received during the monitoring period (2015-2019), with a total duration of 97 hours 36 minutes 35 seconds. The total monitoring time was 7123 camera trap days. Table 1 shows the main temporal and technical characteristics of the monitoring.

\section{Methodology for data processing}

The unit of calculation was the number of independent visits, for each the date, start time, duration of the visit, sex, relative age of the individual (adult, yearling — "one and a half years old", calf - ), which is easily determined by the body size, identification number of the individual, the presence of calves (noted in a separate column in the relation of females), their number and sex, males characteristics of antlers at different stages of growth (velvet antlers/clear antlers) in shape (spike/ fork/ cervicorn/ palmicorn) and the number of tines were recorded. Each moose was identified by individual characteristics (Sedikhin \& Masaitis, 2018; Sedikhin, 2018, 2020), the main of which are the size and shape of the "bell" and antlers, the stage of molting (the presence of bald patches, their shape and size), the presence of calves, the size and shape of wounds on the legs made by gnat, the presence of other injuries/diseases. Morphological and indirect signs identified with camera traps can reliably indicate the individuality of moose in a limited and differentiated period (Sedikhin, 2018, 2020).

To clarify the status of the visit, the category of visits was added as an assessment - "geophagous", when the individual started to eat salt, or "passing", when the individual passed by or did not start licking salt during the entire visit. The category "time for a break in salt licking" was also added, since quite often moose leave the salt lick for less than 30 minutes (this period of time is positioned by the author as determining in the allocation of an independent visit to the same individual, as well as the individuality of moose), they lay down in the zone of the camera actions without salt licking, or their behavior 
Table 1. The main time characteristics of the monitoring.

\begin{tabular}{|l|c|c|c|c|c|c|}
\hline Month & $\begin{array}{c}\text { Number of } \\
\text { observation } \\
\text { periods }\end{array}$ & $\begin{array}{c}\text { Max. number } \\
\text { of observation } \\
\text { points for } \\
1 \text { season }\end{array}$ & $\begin{array}{c}\text { Possible } \\
\text { monitoring time, } \\
\text { day }\end{array}$ & $\begin{array}{c}\text { Camera trap } \\
\text { days }\end{array}$ & $\begin{array}{c}\text { \% of monitoring } \\
\text { time from } \\
\text { possible }\end{array}$ & $\begin{array}{c}\text { General } \\
\text { number of } \\
\text { registered visits } \\
\text { to salt licks by } \\
\text { moose, pcs }\end{array}$ \\
\hline April & 15 & 6 & 450 & 343 & $76 \%$ & 198 \\
\hline May & 34 & 14 & 1054 & 761 & $72 \%$ & 765 \\
\hline June & 34 & 14 & 1020 & 880 & $86 \%$ & 981 \\
\hline July & 35 & 15 & 1085 & 967 & $89 \%$ & 713 \\
\hline August & 32 & 15 & 992 & 938 & $95 \%$ & 549 \\
\hline September & 32 & 14 & 960 & 897 & $93 \%$ & 409 \\
\hline October & 30 & 13 & 930 & 845 & $91 \%$ & 316 \\
\hline November & 28 & 11 & 840 & 650 & $77 \%$ & 195 \\
\hline December & 12 & 7 & 372 & 285 & $77 \%$ & 70 \\
\hline January & 7 & 4 & 217 & 217 & $100 \%$ & 26 \\
\hline February & 7 & 4 & 198 & 193 & $97 \%$ & 21 \\
\hline March & 5 & 4 & 155 & 147 & $95 \%$ & 20 \\
\hline In total & - & - & 8273 & 7123 & - & 4263 \\
\hline
\end{tabular}

over several recordings indicates a lack of interest in salt. Also "pure visiting time" and the identification number of "last year" or "... from neighboring salt licks" were added, in the case of identification of the same individuals on separate experimental plots on two or more salt licks or over several years. To calculate the attendance rates, the amount of material received and the camera trap days (the working time of the camera at the monitoring point) were determined. Data recording were carried out in Microsoft Excel.

\section{Data analysis techniques}

At the beginning of the monitoring, subjectively, based on the data obtained, 6 sex and age groups, hypothetically different, were identified: adult males, one and a half years old males (yearling bulls), adult single females, one and a half years old females (yearling cows), adult females with calves, adult females with yearling individuals. The last group was selected based on a long-term (from April to October) observation on one of the salt licks in the Tosnensky district of a group of individuals consisting of an adult female and a yearling female, which were present together throughout the entire period. At the same time, similar groups of individuals were singularly recorded later on other mineral licks. When analyzing the characteristics of visits during the year, no separate time periods were identified, but the dates of the beginning and end of the months were used as the main boundaries of the studied periods. The duration of visiting salt licks for individuals $<1$-year-old was calculated from October to March, since during the rutting season and after it they show more independence and often present on salt licks alone. However, in cases of visiting salt licks by calves alone in other months, it was also calculated separately. In the case of calves visiting salt licks during the period from October to March together with an adult female, the duration of the salt licking of each calf was calculated, but a separate visit was not singled out but was characterized as a visit by the adult female with the calves.

To determine the parameters of the distributions and calculate the average values for hypothetical groups, the Matlab2019R program was used, the CurveFitting application was used to approximate the distributions by functions. Mean value was determined for following data: 1) the duration of visits for the entire period, including passing visits, i.e. the average duration of the presence of moose on the artificial salt lick and in close proximity to it for 1 visit; 2) for all geophagous visits without (= all geophagous durations) and with (= all geophagous duration - time of breaks) taking breaks into account; 3 ) the duration of geophagous visits with taking breaks into account for each of the identified groups of individuals; 4) the duration of all/ geophagous visits without/ with taking breaks into account for each month; 5) duration of geophagous visits without taking breaks into account by adult and yearling sex groups (females/ males) by month. For this calculation, author used the data of the duration of geophagous visits without taking breaks into account in order to show the full values of the duration of the presence of individuals in close proximity to a salt lick during geophagy, and not only the time of the process itself. The calculations for autumnwinter months did not include salt licking durations of calves accompanying an adult female during visiting mineral lick, since this could lead to a distortion of the average duration values corresponding to salt licking of independent individuals. For the other measurements, these data were too insignificant to cause serious bias, so they were included in the total sample.

To identify differences in the duration of attendance between the groups of individuals and the calculated categories of geophagous visits by months, the Student's t-test was used. The weighted averages were compared 


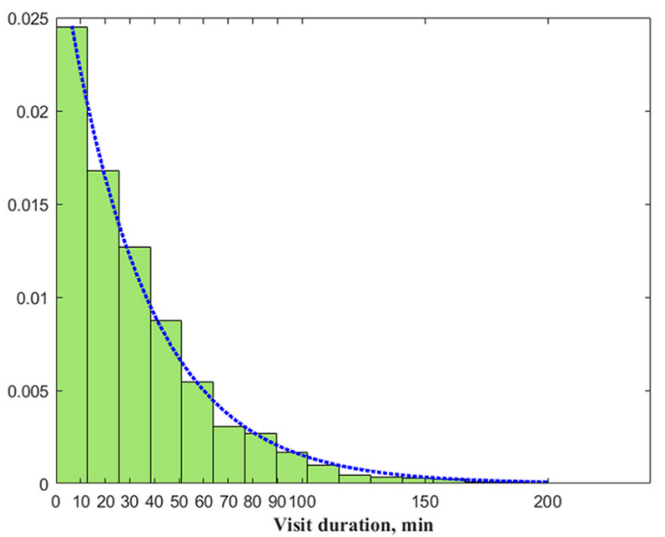

Fig. 1. Probability density of duration data of all visits (exponential distribution: $\lambda=0.0297 \mathrm{~min}^{-1} ; \mathrm{R}^{2}=0.996$ ).

with each other in pairs. The results of the comparisons are graphically visualized on the matrix with the color scale indication of the reliability of the differences.

Diurnal activity graphs were drawn up using QB64. The main idea of the design was to visualize all salt licking periods during the day on one graph related to a certain month. At each intersection, each area receives a color index according to automatic gradation. Black color marks the ranges in which there was a minimum number of salt licking periods, on the contrary, the areas of intersection of the maximum number of visits are painted with the brightest white color. Also, on each graph, the periods of sunrise and sunset during the studied month are marked with a special range (data are given for St. Petersburg), the time and values of the maximum number of intersecting periods (Global Max) on the graph are given.

\section{Results}

Salt licking. Duration and frequency. Diurnality and seasonality

During the monitoring period (2015-2019), all age and sex groups of individuals mentioned in the method were recorded. Moose visit salt licks all year round, however, most actively from May to August. In the rest of the year, the most important salt licks periods are April and October. Results from cameras left for the winter months (December-March) showed that this is a period of the least active visits.

Based on the observation results, 4420 cases of visits were analyzed for the evaluation of the duration of salt licking for different groups of individuals. Least of all measurements were made in 3 groups: calves of both sexes and adult females with yearlings. All data by sex and age groups excluding breaks, including passing visits, have the form of an exponential distribution (1), with $\lambda=(29.7 \pm 1.2) \cdot 10^{(-3)} \mathrm{min}^{-1}$ (confidence probability is $95 \%$ ) (Fig. 1). The data of the duration of visits for each of the age and sex groups, as well as all the data

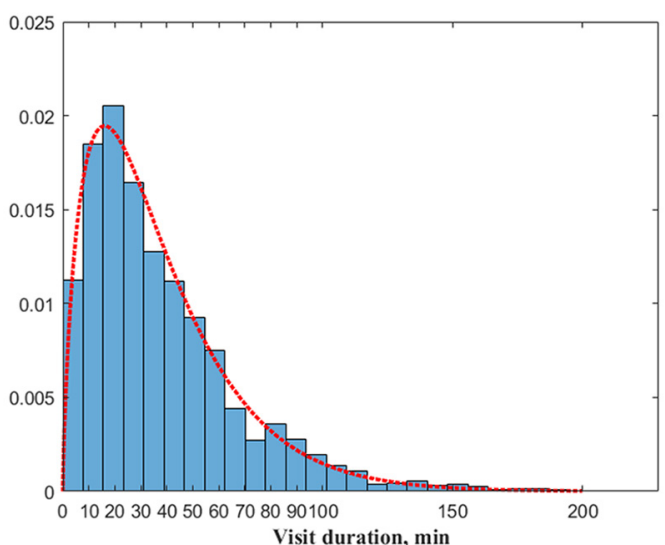

Fig. 2. Probability density of duration data of all geophagous visits without taking breaks into account (gamma distribution: $\mathrm{k}=1.76 ; \mathrm{t}=21.20 \mathrm{~min} ; \mathrm{R}^{2}=0.991$ ).

of the duration of only geophagous visits, have the form of a gamma distribution (2), with $k=1.76 \pm 0.087 ; \theta=$ $21.20 \pm 1.501 \mathrm{~min}$ (confidence probability is 95\%) (Fig. 2).

$$
\begin{aligned}
& f(x)=\left\{\begin{array}{c}
\lambda \cdot e^{-\lambda x}, x \geq 0 \\
0, x<0
\end{array}\right. \\
& f(x)=x^{k-1} \cdot \frac{e^{\frac{-x}{\theta}}}{\Gamma(k) \cdot \theta^{k}}
\end{aligned}
$$

Table 2 shows mean values of the duration for the main data categories and hypothetically identified age and sex groups. The average duration of geophagous visits without taking breaks into account according to Student's t-test significantly differs $(p<0.05)$ from the average duration of geophagous visits with taking breaks into account and the duration of all visits, including the passing visits. As for the salt licking duration of groups of individuals, significant differences were found between adult individuals and yearling individuals (Fig. 3). The differences between adult males, adult females with calves, and adult single females are not significant. Also, there is no significant difference in the average duration between adult females with yearlings, female calves and adult single females. The maximum residence time of a moose on the salt lick is 229 minutes (an adult male lying near salt lick, September). The maximum duration of the geophagous visit is 174 minutes (female calf, October), the maximum duration of the geophagous visit of an adult moose is 117 minutes (an adult female, June).

Table 3 shows the results of calculating the average duration by month. February is characterized by an exponential distribution of duration data of geophagous visits; for all other months, the data have the form of a gamma distribution. The most reliable duration values are determined for April-December. For January-March, mean errors are given with a confidence level of $68 \%$. 


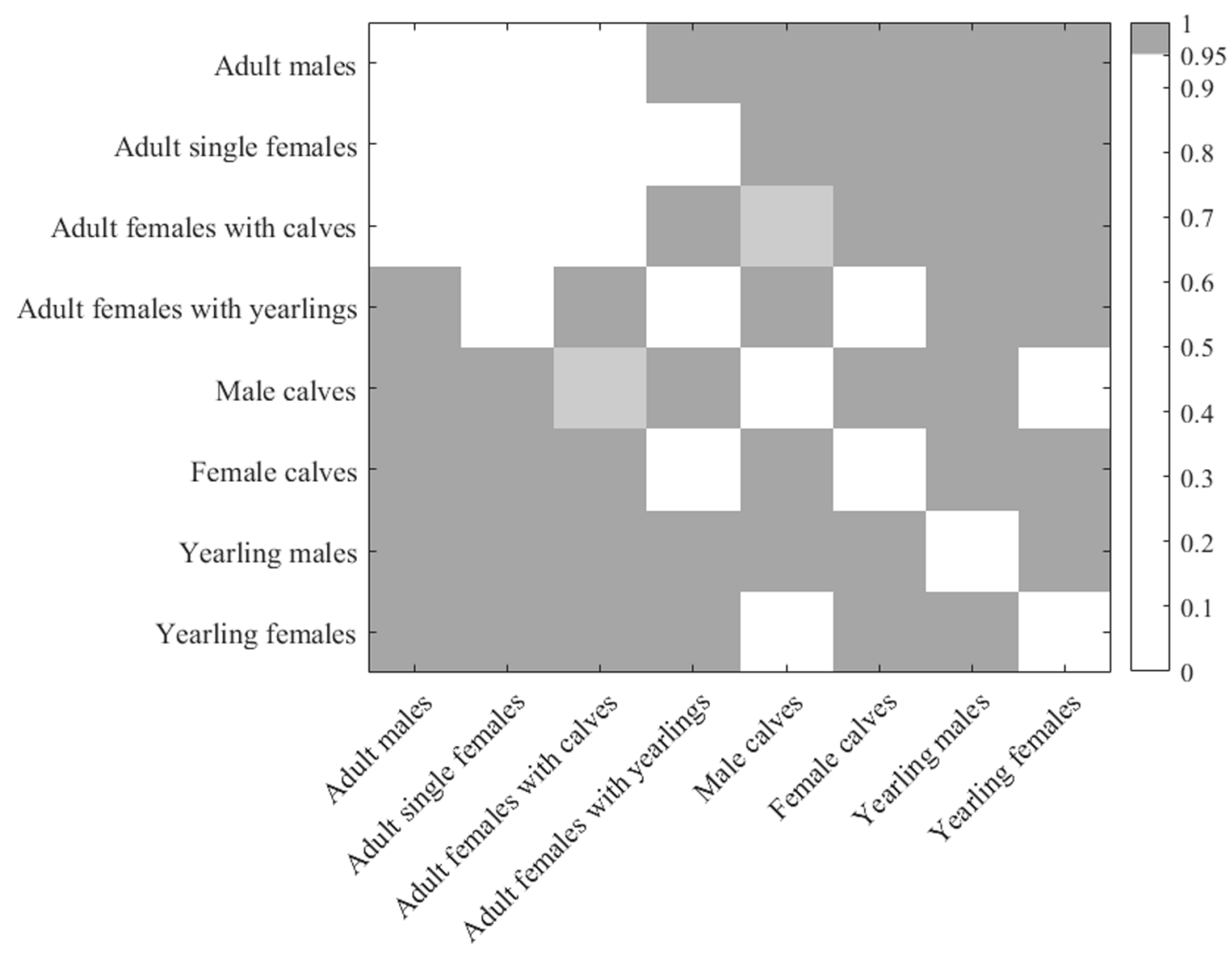

Fig. 3. Significance of differences in the duration of visits according to Student's t-test between hypothetically selected groups of individuals.

Significant differences in the average duration of visits between the category "all visits" and "all geophagous visits without taking breaks into account" were noted in February, April, May, June, September, October and November. Between the categories "all visits" and "all geophagous visits with taking breaks into account", significant differences were noted in July, August, September and November. Significant differences between the two groups of categories of geophagous visits were noted from May to November (Fig. 4).

Table 4 presents data of the average duration of salt licking of individuals by month, divided them based on sex. It should be noted that in all groups of individuals, the average duration is close to half an hour. At the same time, it changes insignificantly by month. The smallest average duration was observed in males in May and September, and in females in May and July. For females, the data of the average error for December are given with a confidence level of $68 \%$, in the remaining months for both sexes with a confidence level of $95 \%$. In the winter months, it was not possible to identify a reliable average duration due to an insufficient number of measurements. Significant differences between females and males were noted in May, July and September.

Speaking about the daily activity of moose on salt licks (Figs 5-7), there is high activity in the dark or twilight, with the peak of attendance occurring within 1-3 hours after sunset. The largest number of intersections (Global Max $=97$ ) was noted in June at 11:28 pm. The change in activity by month was also visually noted. The conditional boundaries are the periods of natural changes in the life cycle of moose: May and September. April, October and November are characterized by a mosaic distribution of the periods of activity during the day, however, for the autumn months, in contrast to April, the peaks are seen to be attached to the pre-dawn and post-sunset periods. The winter months are represented by the least attendance; however, the daily activity is probably similar to the activity in the autumn period.

The patterns of visiting mineral licks are similar for all individuals. The general view of individual salt licking consists of alternating periods of visiting artificial salt licks (not more than 4 days in a row) with longer breaks between the next period of visiting. During the days of salt licking, the same individual most often visits the lick several times. This is evidenced by the data of the number of visits by the days of visits to the salt lick. Depending on the month and salt lick, they vary from 1 to 11 visits per day (most often $1-5-99 \%$ cases), on average $1.48 \pm 0.39$ (gamma distribution, $\mathrm{R}^{2}=0.99$; $\mathrm{p}<0.05$ ), thereby allowing us to assert that individuals most often visit lick several times in a day of salt 


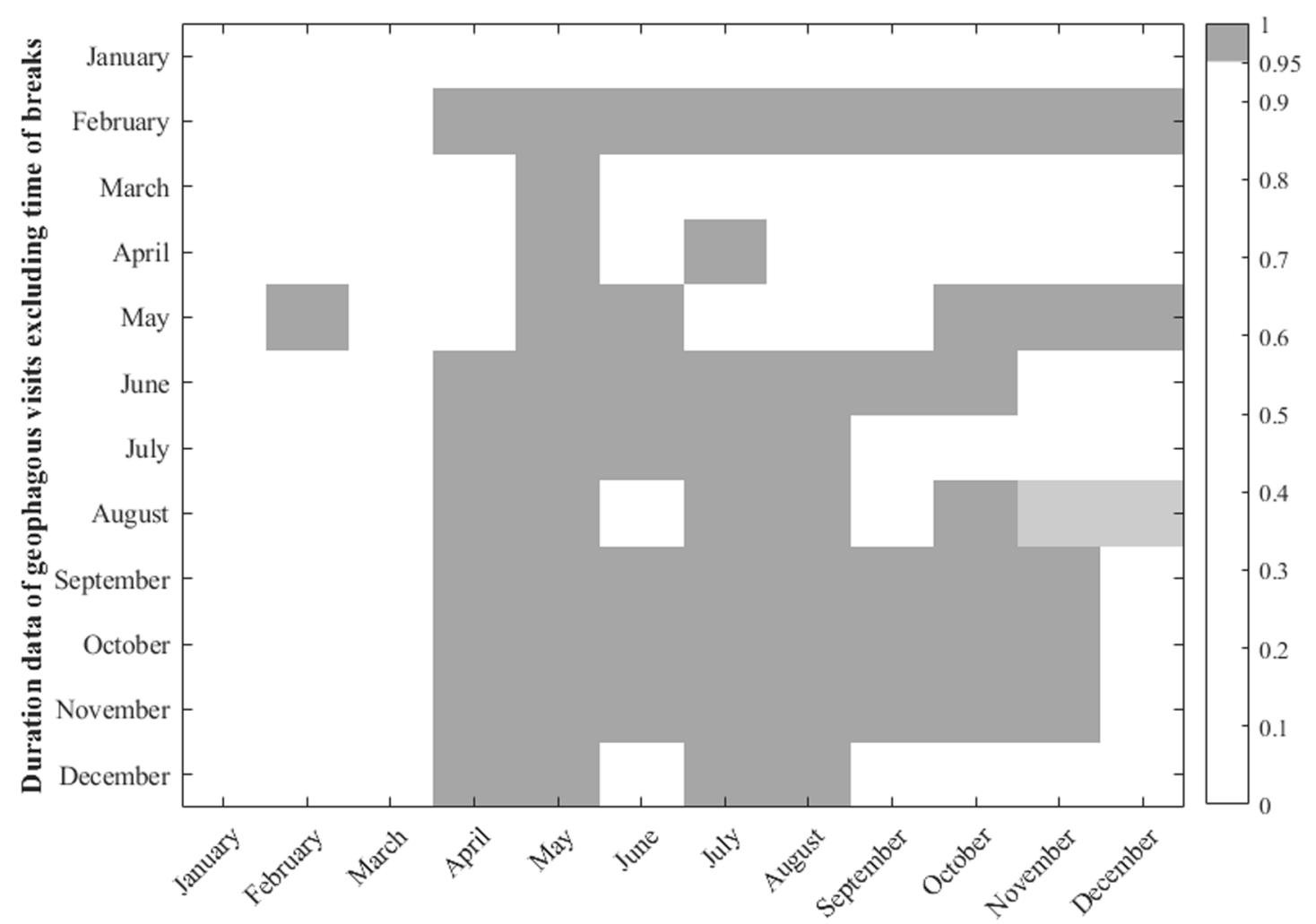

Duration data of geophagous visits including time of breaks

Fig. 4. Significance of differences in the duration of visits between the two categories of geophagous visits according to Student's t-test by month.

Table 2. The main characteristics of the model series of probability densities by groups of data for all time ( $\mathrm{N}$ - the number of measured independent visits).

\begin{tabular}{|l|c|c|c|c|c|c|}
\hline \multicolumn{1}{|c|}{ Data groups } & $\mathrm{N}$ & $\mathrm{R}^{2}$ & $\begin{array}{c}\lambda \pm 2 \sigma, \\
\mathrm{min}^{-1}\end{array}$ & $\mathrm{k} \pm 2 \sigma$ & $\begin{array}{c}\mathrm{t} \pm 2 \sigma, \\
\text { min }\end{array}$ & $\begin{array}{c}\text { Mean value of } \\
\text { the duration of } \\
\text { visits, min } \pm 2 \sigma\end{array}$ \\
\hline All recorded salt licking durations & 4420 & 0.997 & $0.0297 \pm 0.00112$ & - & - & $33.7 \pm 1.3$ \\
\hline $\begin{array}{l}\text { All geophagous visits without } \\
\text { taking breaks into account }\end{array}$ & 3587 & 0.991 & - & $1.76 \pm 0.09$ & $21.20 \pm 1.50$ & $37.3 \pm 4.5$ \\
\hline $\begin{array}{l}\text { All geophagous visits with taking } \\
\text { breaks into account }\end{array}$ & 3587 & 0.995 & - & $1.73 \pm 0.06$ & $19.17 \pm 0.94$ & $33.2 \pm 2.8$ \\
\hline Adult males & 1019 & 0.982 & - & $1.84 \pm 0.12$ & $19.59 \pm 1.83$ & $36.1 \pm 5.8$ \\
\hline Adult single females & 541 & 0.985 & - & $1.65 \pm 0.15$ & $22.57 \pm 3.03$ & $37.2 \pm 8.4$ \\
\hline Adult females with calves & 841 & 0.990 & - & $1.71 \pm 0.11$ & $20.65 \pm 1.82$ & $35.4 \pm 5.3$ \\
\hline Adult females with yearlings & 91 & 0.973 & - & $1.26 \pm 0.24$ & $33.02 \pm 9.03$ & $41.6 \pm 19.3$ \\
\hline Male calves & 84 & 0.976 & - & $1.83 \pm 0.32$ & $17.09 \pm 4.23$ & $31.3 \pm 13.2$ \\
\hline Female calves & 94 & 0.995 & - & $2.87 \pm 0.15$ & $14.46 \pm 1.37$ & $41.5 \pm 6.1$ \\
\hline Yearling males & 307 & 0.989 & - & $1.96 \pm 0.17$ & $12.70 \pm 1.50$ & $24.9 \pm 5.0$ \\
\hline Yearling females & 610 & 0.994 & - & $2.08 \pm 0.13$ & $13.48 \pm 1.14$ & $28.0 \pm 4.1$ \\
\hline
\end{tabular}


Table 3. Average duration of visits by the category of visits by month ( $\mathrm{N}$ - the number of measured independent visits).

\begin{tabular}{|l|c|c|c|c|c|c|c|c|c|}
\hline \multirow{3}{*}{ Month } & \multicolumn{3}{|c|}{$\begin{array}{c}\text { All visits (geophagous and } \\
\text { passing), min }\end{array}$} & \multicolumn{2}{c|}{$\begin{array}{c}\text { All geophagous visits without } \\
\text { taking breaks into account, min }\end{array}$} & \multicolumn{2}{c|}{$\begin{array}{c}\text { All geophagous visits with taking } \\
\text { breaks into account, min }\end{array}$} \\
\cline { 2 - 13 } & $\mathrm{N}$ & $\begin{array}{c}\text { Mean } \\
\text { value, min }\end{array}$ & $\pm 2 \sigma, \min$ & $\mathrm{N}$ & $\begin{array}{c}\text { Mean } \\
\text { value, min }\end{array}$ & $\pm 2 \sigma, \min$ & $\mathrm{N}$ & $\begin{array}{c}\text { Mean } \\
\text { value, min }\end{array}$ & $\pm 2 \sigma, \min$ \\
\hline April & 199 & 30.2 & 4.75 & 161 & 36.0 & 16.8 & 161 & 31.7 & 11.4 \\
\hline May & 783 & 29.4 & 1.53 & 641 & 33.3 & 6.82 & 641 & 28.5 & 6.43 \\
\hline June & 984 & 33.7 & 2.18 & 812 & 39.7 & 5.84 & 812 & 35.1 & 8.46 \\
\hline July & 713 & 36.8 & 1.92 & 600 & 37.2 & 9.56 & 600 & 32.0 & 6.53 \\
\hline August & 549 & 36.7 & 3.27 & 452 & 35.7 & 5.33 & 452 & 32.6 & 7.44 \\
\hline September & 410 & 27.8 & 2.42 & 295 & 42.0 & 11.7 & 295 & 35.0 & 13.0 \\
\hline October & 317 & 37.7 & 1.85 & 245 & 43.4 & 11.4 & 245 & 37.3 & 5.58 \\
\hline November & 195 & 34.1 & 2.57 & 145 & 43.0 & 6.4 & 145 & 38.1 & 8.82 \\
\hline December & 70 & 36.8 & 3.81 & 58 & 40.2 & 20.1 & 58 & 39.8 & 14.9 \\
\hline January & 26 & 26.9 & 11.3 & 19 & 33.6 & 18.7 & 19 & 30.4 & 27.7 \\
\hline February & 18 & 34.2 & 11.3 & 15 & 48.7 & 10.2 & 15 & 45.9 & 13.4 \\
\hline March & 22 & 37.6 & 9.73 & 17 & 44.0 & 18.4 & 17 & 44.9 & 30.5 \\
\hline
\end{tabular}

Table 4. Average duration of geophagous visits without taking breaks into account by sex groups by month ( $\mathrm{N}$ - the number of measured independent visits).

\begin{tabular}{|l|c|c|c|c|c|c|}
\hline \multirow{2}{*}{ Month } & \multicolumn{3}{|c|}{ Males } & \multicolumn{3}{c|}{ Females } \\
\cline { 2 - 7 } & $\mathrm{N}$ & Mean value, min & $\pm 2 \sigma, \min$ & $\mathrm{N}$ & Mean value, min & $\pm 2 \sigma, \min$ \\
\hline April & 58 & 33.6 & 16.7 & 103 & 31.8 & 20.8 \\
\hline May & 293 & 28.2 & 8.25 & 348 & 29.8 & 3.23 \\
\hline June & 294 & 36.0 & 7.68 & 518 & 34.5 & 6.31 \\
\hline July & 238 & 37.6 & 10.1 & 350 & 29.6 & 9.75 \\
\hline August & 128 & 30.5 & 10.3 & 321 & 33.2 & 7.91 \\
\hline September & 109 & 29.3 & 16.0 & 183 & 38.6 & 10.6 \\
\hline October & 95 & 36.9 & 15.2 & 143 & 37.4 & 12.5 \\
\hline November & 74 & 36.9 & 15.6 & 59 & 36.4 & 21.6 \\
\hline December & 21 & 39.8 & - & 31 & 42.7 & 22.0 \\
\hline January & 2 & 42.5 & - & 15 & 27.7 & - \\
\hline February & 6 & 51.6 & - & 8 & 23.8 & - \\
\hline March & 8 & 43.8 & - & 4 & 47.0 & - \\
\hline
\end{tabular}

licking, and they visit the same salt licks while living in groups (Zaitsev, 2017). The number of visits to the same salt lick by different individuals varies from 1 to 19 per day (most often $1-5-95 \%$ cases), on average $2.11 \pm 0.46$ (gamma distribution, $\mathrm{R}^{2}=0.99 ; \mathrm{p}<0.05$ ). The percentage of visiting days per month varies from zero in March to $100 \%$ in June. On average, there are about a third $(34.9 \% \pm 20.8 \%)$ of the days of the month, on which visits are recorded (gamma distribution $\mathrm{R}^{2}=$ $0.98 ; \mathrm{p}<0.05)$. The percentage of visits to salt licks by generalized groups is shown in Figure 8.

The behavior of moose on salt licks and flocking

Depending on the place and year of monitoring, from 5 to 33 different individuals were recorded on each salt lick. The largest number of different individuals who visited the salt lick was noted in May $(\mathrm{n}=18)$, June $(\mathrm{n}=$ $20)$ and October $(n=20)$. The total number of registered moose for monitoring period (2015-2019) cannot be quite reliably determined without additional analysis and systematized information for each individual. Since some mineral licks have been observed for several years in a row, in addition to previously unrecorded individuals, the same sedentary moose could be "captured".

Most often visit salt licks alone (65.9\% of cases) or in small groups of two (19.3\%) or three individuals $(13.1 \%)$. Moreover, most of these groups are females with calves. Groups of two yearling "twins" of both males and females are also common. Groups of more than four individuals (1.7\% of cases) consist of animals of different ages. The basis of such groups is most often made up of females with calves. Groups of more than four individuals were recorded from May to December, most often in June and September, while, probably, the reasons for the appearance of such groups were different. In June, the salt licks become places of concentration, which several individuals can enter at the same time, 


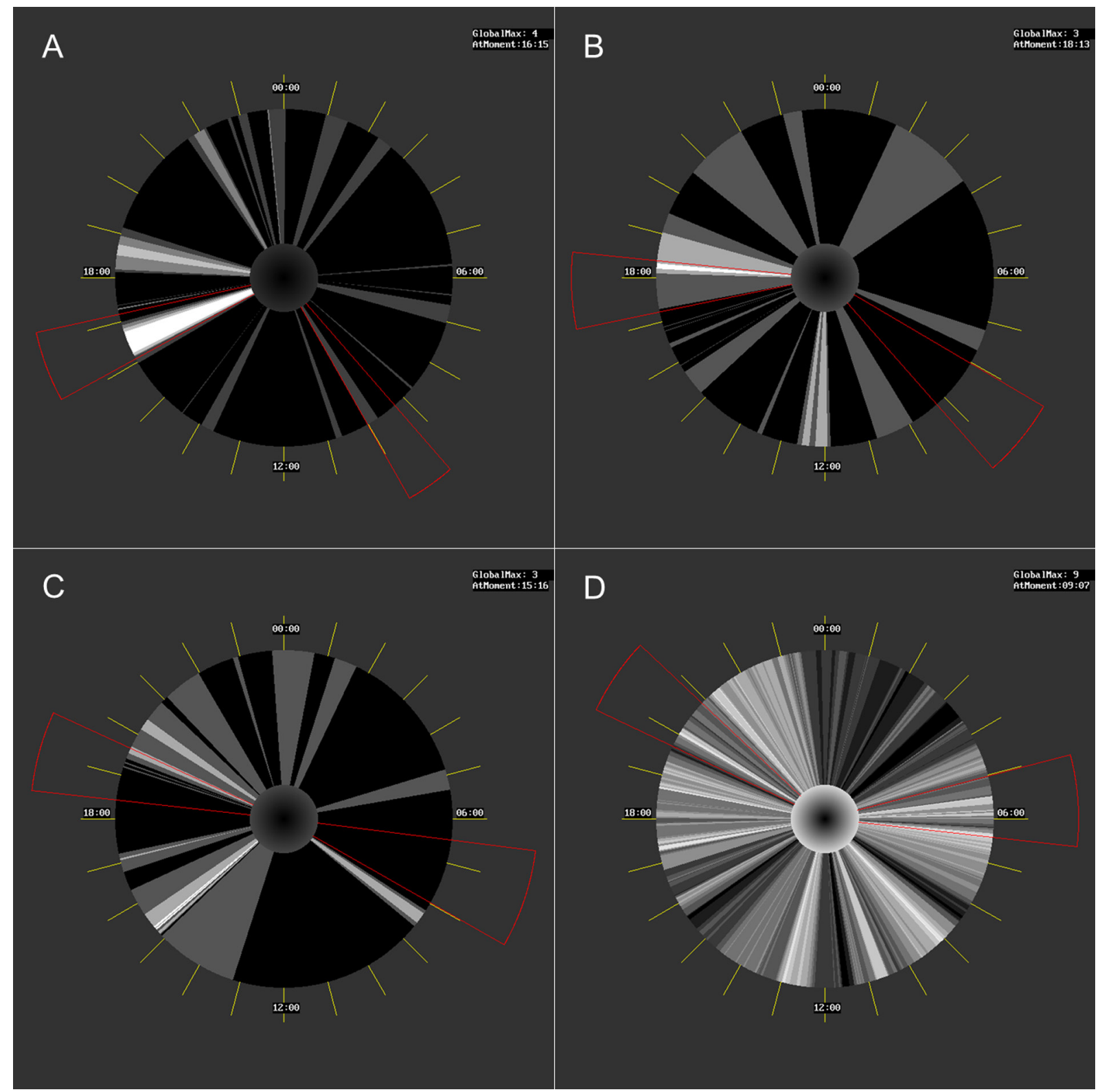

Fig. 5. Diagram of daily activity of moose on salt licks (A - January; B - February; C - March; D - April).

and in September these groups are formed due to the mating period. The largest recorded group of individuals consisted of 7 animals.

Intraspecific competition manifests itself hierarchically. Adult large males displace weaker males and females with calves from salt licks; however, at the same time, having a larger habitat area according to the literature data (Cederlund \& Sand, 1994; van Beest et al., 2011; Bjorneraas et al., 2012), they can leave the observed salt lick for a long time, "providing" it to other individuals.

It is worth noting an important behavioral aspect in salt licking of yearling males since they are more prone to competition than yearling females. Adult females are more loyal to yearling females than to yearling males: adult females accompanied by yearling males were observed in $41 \%$ of cases of registration of this group, while all these cases were noted in April, and $80 \%$ of cases of this accompaniment yearling males were also in the presence of their twins - yearling females. The remaining 59\% of cases were accompanied by one or two young females.

Also, tough competition from older males to yearlings is not excluded. Some of the videos obtained suggest that neutrality towards adult males takes place only if the males are morphologically close to each other. There was no significant competition between visually similar-aged animals. In the case where there are clear differences in weight, antlers (and, accordingly, age), there was a clear advantage of the older and stronger individual. 


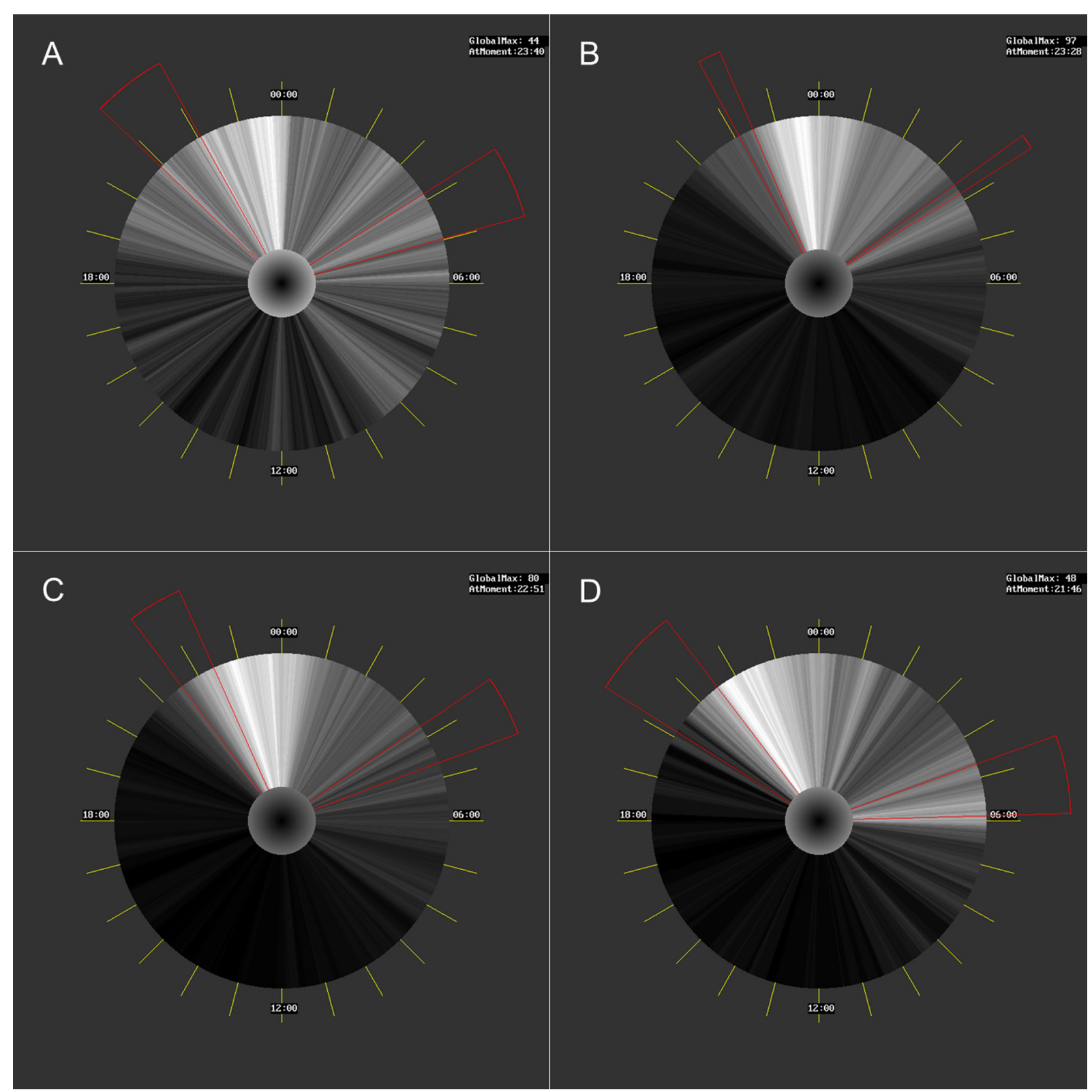

Fig. 6. Diagram of daily activity of moose on salt licks (A - May; B - June; C - July; D — August).

When processing data from camera traps, significant informativeness of video materials was revealed, which allows one to draw conclusions not only about the sex, age and individuality of the registered individuals but also about behavioral characteristics. It has been reliably noted that moose are neutral towards birds and small mammals (representatives of the family Mustelids, Hare-like, Rodents). Moose are wary of the approach of any large animal, including other individuals. Wild boars cause moderate anxiety, but usually when this kind of meeting happens, boar leaves first. In the event of meeting a herd of wild boars, adult moose may exhibit aggression. When large predators (wolf, bear) visit salt licks, moose either leave the salt lick 5-10 minutes before the appearance of predators or use a long-term model of behavior, avoiding both the salt lick and the territory visited by a predator. Based on 5 observations it is possible to mark that adult large males are more neutral towards predators than young individuals and females with calves. The latter group, which is most susceptible to attack, has a specific behavior of avoiding predators.

\section{Additional monitoring results}

In addition to European Moose, European Badger (Meles meles (Linnaeus, 1758)), European Pine Marten (Martes martes (Linnaeus, 1758)), Least Weasel (Mustela nivalis Linnaeus, 1766), European Polecat (Mustela putorius Linnaeus, 1758), Brown Bear (Ursus arctos 


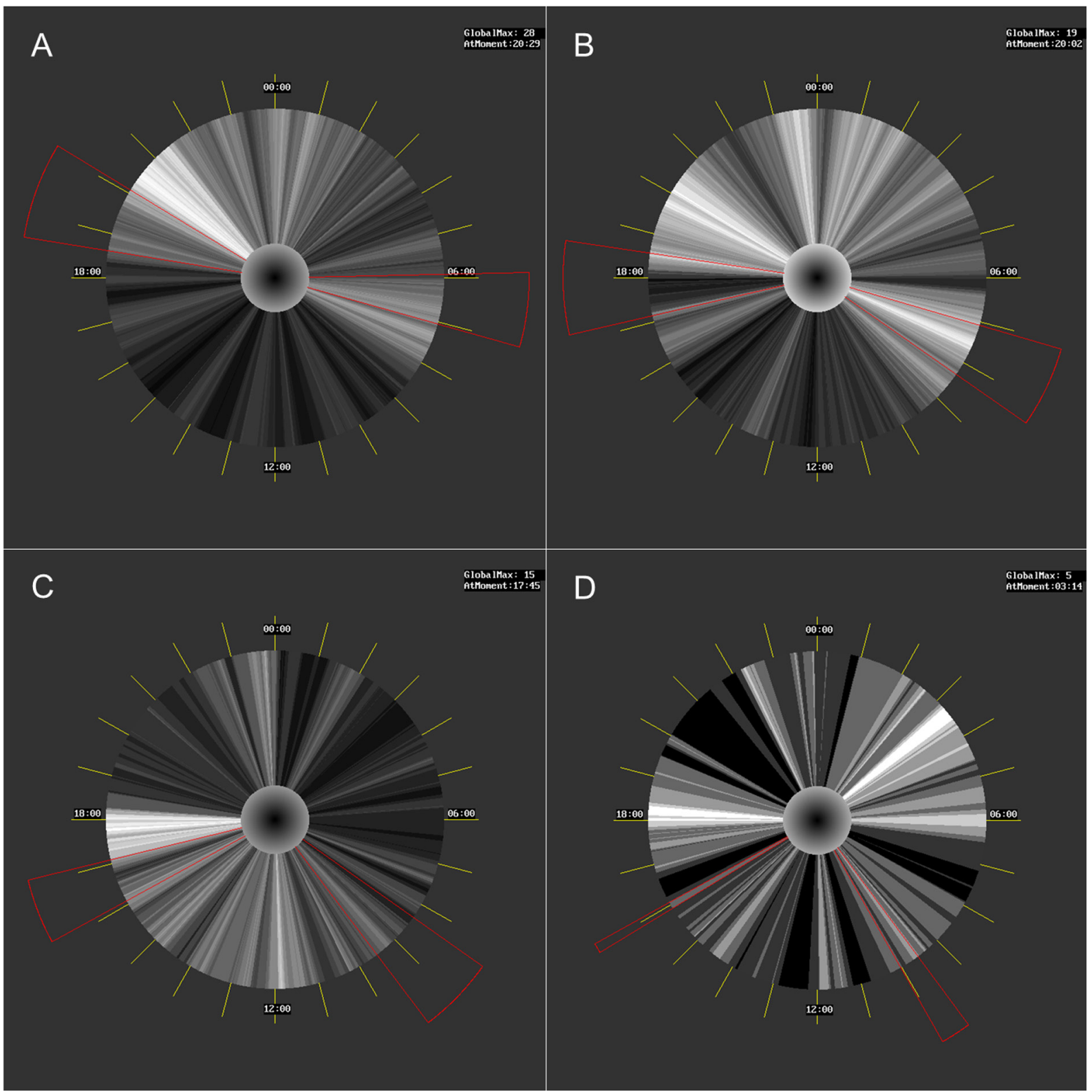

Fig. 7. Diagram of daily activity of moose on salt licks (A — September; B — October; C — November; D — December).

Linnaeus, 1758), Eurasian Lynx (Lynx lynx (Linnaeus, 1758)), Red Fox (Vulpes vulpes (Linnaeus, 1758)), Raccoon Dog (Nyctereutes procyonoides (Gray, 1834)), Wolf (Canis lupus Linnaeus, 1758), Mountain Hare (Lepus timidus Linnaeus, 1758), Eurasian Red Squirrel (Sciurus vulgaris Linnaeus, 1758), Wild Boar (Sus scrofa Linnaeus, 1758), European Roe (Capreolus capreolus (Linnaeus, 1758)) and undetermined representatives of Chiroptera Blumenbach, 1779 and Myomorpha Brandt, 1855 were recorded on salt licks. The following bird species have also been determined on the sites: Common Wood Pigeon (Columba palumbus Linnaeus, 1758), Hazel Grouse (Tetrastes bonasia (Linnaeus, 1758)), Western Capercaillie (Tetrao urogallus Linnaeus,
1758), Eurasian Nutcracker (Nucifraga caryocatactes (Linnaeus, 1758)), Common Raven (Corvus corax Linnaeus, 1758), Eurasian Jay (Garrulus glandarius (Linnaeus, 1758)), Eurasian Blackbird (Turdus merula Linnaeus, 1758), Song Thrush (Turdus philomelos Brehm, 1831), Fieldfare (Turdus pilaris Linnaeus, 1758), Mistle Thrush (Turdus viscivorus Linnaeus, 1758), Common Crane (Grus grus (Linnaeus, 1758)), Common Chaffinch (Fringilla coelebs Linnaeus, 1758), Eurasian Nuthatch (Sitta europaea Linnaeus, 1758), European Robin (Erithacus rubecula (Linnaeus, 1758)), Tits (Parus Linnaeus, 1758), Eurasian Woodcock (Scolopax rusticola Linnaeus, 1758), Great Spotted (Dendrocopos major (Linnaeus, 1758)), Lesser Spotted 


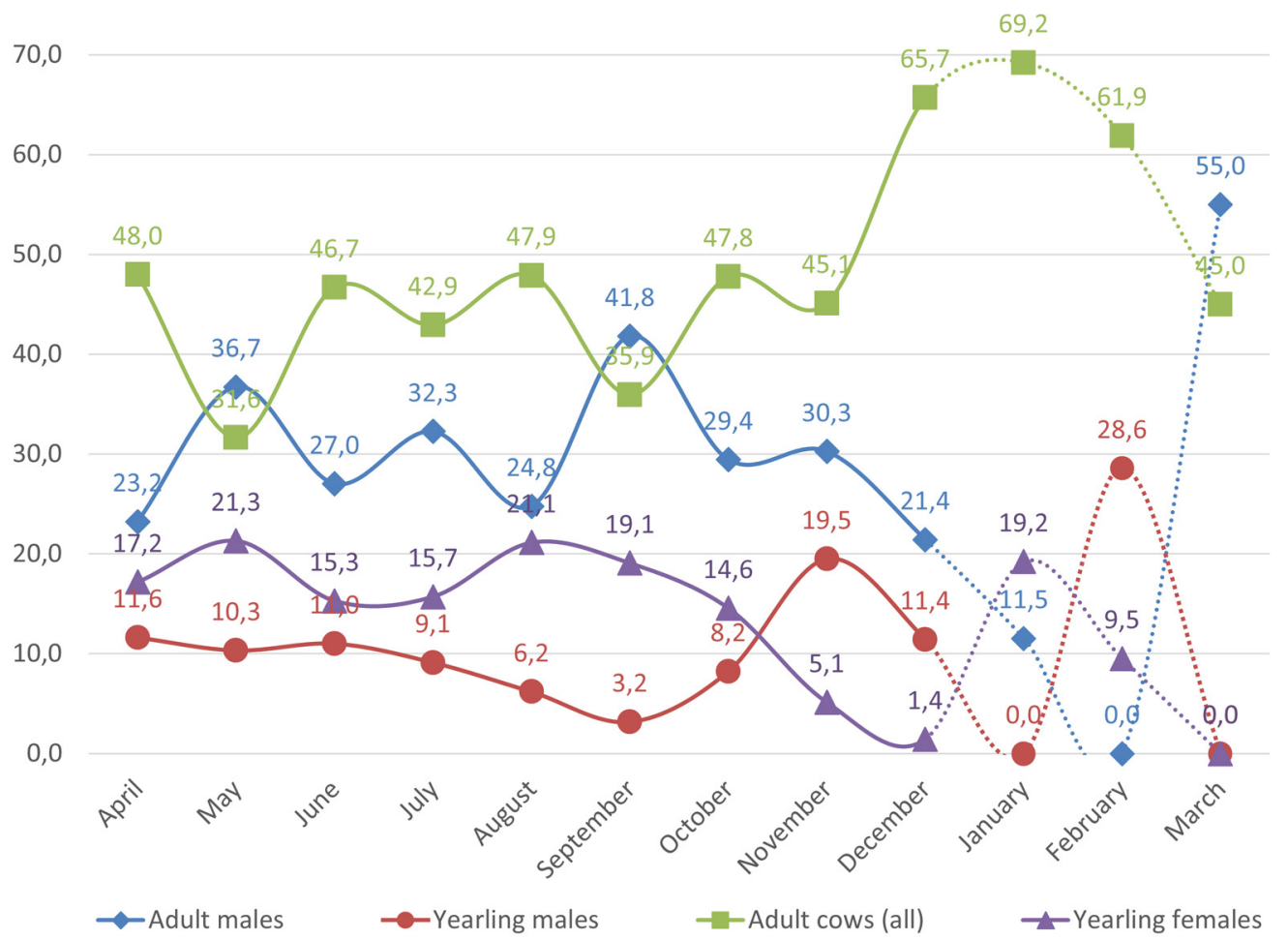

Fig. 8. Percentage of registered visits by groups of individuals by month.

(Dryobates minor (Linnaeus, 1758)), Black (Dryocopus martius (Linnaeus, 1758)) and Eurasian Three-toed (Picoides tridactylus (Linnaeus, 1758)) Woodpeckers, Northern Goshawk (Accipiter gentilis (Linnaeus, 1758)), Red-footed Falcon (Falco vespertinus Linnaeus, 1766), Owls (Strigiformes Wagler, 1830), Hen Harrier (Circus cyaneus (Linnaeus, 1766)). Thus, camera traps monitoring on artificial salt licks is suitable not only for researching life peculiarities of large ungulates, but also for estimating biodiversity and the relative abundance of other vertebrate species.

\section{Discussion}

The average duration of geophagous visits with taking breaks into account, does not significantly differ from the average duration of all visits, although the data of both groups have different density distributions. Therefore, in similar studies, it is worth separating not only geophagous groups of visits but also these 2 groups and specify for which of the groups the data is presented.

The results obtained for the average duration of visits are nevertheless close to those from North America (Jordan et al., 1973; Fraser \& Hristienko, 1981; Risenhoover \& Peterson, 1986; Ayotte et al., 2008;), but it is rather difficult to carry out a qualitative comparison with the data of other authors due to discrepancies in the calculation method. At the same time, there are rather strange differences: in the study of the geophagous activity in Ontario (Fraser \& Hristienko, 1981) the results of the average duration of salt licking of adults are much less (males, $26.6 \pm 1.9 \mathrm{~min}$; females, $26.9 \pm 2.9 \mathrm{~min}$ ) than the yearling's (males, $37.1 \pm 4.6 \mathrm{~min}$; females, $37.6 \pm$ $4.6 \mathrm{~min}$ ), at the same time, the data obtained are directly opposite (Table 2). In a study of the attendance of natural mineral licks in British Columbia (Ayotte et al., 2008), the authors note that the average duration of moose salt licking was always less than 40 minutes; however, they note that no significant differences between sex were found, while in this study significant differences between females and males are noted in May, July and September. In Central Yakutia (Stepanova et al., 2016, 2017), the average duration of geophagy is $8.7 \pm 7.8 \mathrm{~min}$, and in South Yakutia 12.0 $\pm 1.0 \mathrm{~min}$ (Stepanova et al., 2018), thus, it does not coincide at all with the received data.

The selected adult groups of individuals do not differ from each other, however, females with yearling individuals are more dependent on each other, thus the duration of salt licking of this group does not differ significantly from single females and calf-females, at the same time it is different from adult males and females with calves. Also, it should be noted that in this research it was impossible to accurately determine the age of an adult individual (all individuals more than 2 years old were considered adults). It is likely that with more accurate identification of the age up to a year the average duration data may differ reliably between older and younger groups like between adults and yearlings in this study. 
The logical differences in the duration of salt licks between yearlings and adults are most likely explained by physiological differences: yearlings are immature, with lower body weight, so they probably replenish sodium deficiency faster or do not perceive it as critically as adults. Moreover, the behavior of yearlings is more active - in the first independent year of life, they actually get to know the surrounding conditions by themselves. Some of them are strongly attached to the places of salt licks, where they were present with an adult female in the previous year of observation.

The presented graphs of daily activity clearly demonstrate the peak values and main periods of salt licking. Focusing on similar investigations it is exceedingly difficult to choose periods that could be compared. The main problem is that in different months the daylight period varies greatly by hours. Attempts to select time ranges are typical for seasonal studies, for example, the spring-summer period of active visits (Fraser \& Hristienko, 1981). The graphs of intersections of the registered salt licking periods presented in figures 5-7 are the most informative in the author's opinion.

The results obtained completely coincide with the conclusions of other authors about the specificity of this phenomenon for all sex-age groups and about the seasonality of the geophagous behavior "... which correlates with phenological events, primarily with the period of the appearance of young juicy greenery, as well as with special physiological states of animals" (Panichev, 2011: 26). In this case food change, pregnancy, lactation, molting, antler growth, rutting period, are suitable as criteria for this term. In April, the growth of antlers in males begins, in adult females begins a period before calving, when they show aggression towards the juveniles of the last year, driving them away from themselves, and probably from their habitat, and then "retire" at the time for calving. Adult females accounted for $48 \%$ of all registered visits in April, while in May this indicator becomes the lowest in a year and was $31 \%$ (Fig. 8). According to meteorological data, July is the warmest month in the Leningrad region, and this period is the peak of aquatic vegetation with high sodium content. Low attendance of salt licks in July (32.3\% of the total visits) and August (24.8\%) by adult males may be due to the fact that moose prefer wetlands in this period.

According to observations, in fall the duration of salt licks in both sexes slightly increases. For the one hand, October is the first month after changing feed and rut. The animals likely need to take in the required amount of sodium make up for losses (especially bulls) during the rut and normalize acid-base balance. On the other hand, the trend of a slight increase in duration can be explained by a natural slowdown in the rhythm of life, which is often mentioned in Russian literature (Knorre, 1959; Timofeeva, 1974; Vereshchagin \& Rusakov, 1979). The amount of feed consumed in comparison with the growing season is reduced by $2-3$ times. Along with this, the attendance of salt licks is decreasing. Cold temperatures and woody food (harder, conditionally dry, radically different from lush summer vegetation) are less conducive to the elimination of sodium from the animal's body. Moose try to minimize energy consumption, which in turn affects the use of different biotopes, primarily staying in the most forage lands. It is likely that the artificial salt licks, on which the monitoring was carried out, belong to the group of "summer" salt licks, and in winter with a high snow cover, visiting them is difficult and physiologically "not justified". Many hunting experts noted the need to organize both "summer" salt licks in summer stations, and "winter" salt licks in winter stations (Martynov et al., 2011), and the necessity of protection the surrounding areas from the anthropogenic disturbance (Rea et al., 2004).

In a similar study in British Columbia (Rea et al., 2013), on the contrary, for 3 years in a row, the peak of attendance was noted precisely in January and February, however, it also monitored a "wet" natural mineral spring. Perhaps in winter it is "more profitable" for moose to absorb not pieces of pure halite, but an aqueous saline solution. The artificial salt licks used as monitoring points in this study were organized from the butt-log portion of an Aspen (Populus tremula Linnaeus, 1753) and contained lumps of "rock salt" consisting mainly of sodium chloride. Thus, in comparison with the conditions on the kudurs, in this study moose had direct access to the hypothetically required substance. It is logical to assume that the satisfaction of sodium needs should be faster than with the absorption of water or clay containing minerals. However, in this case, the stomach does not fill, so the elk probably does not feel full and continues licking for a longer time.

Some authors have argued that the sodium content of the plants eaten by moose is so low that it cannot meet its requirements from vegetation alone (Jordan et al., 1973). Sources of minerals in the study area are limited. They can affect the distance between groups of individuals, creating places of concentration, thus lead to competition for access to them. This aspect is indirectly confirmed by observations of different age and sex groups on salt licks. Probably, there are differences between the groups of individuals resident in the territory and those who reside there temporarily, however, these groups have not been reliably identified yet. According to the "field" material in habitat areas where several salt licks were monitored, resident individuals usually visit one "favorite" lick, rare visiting others.

\section{Conclusion}

For the first time, based on a large sample, reliable information about the geophagous activity of the moose on artificial salt licks in the North-West of Russia was obtained. Estimated durations are given for each group of individuals and categories of visits. The average duration of a visit is close to half an hour for each of the hypothetically identified groups of individuals. The reliability of differences between groups of individuals and categories of visits was assessed. In the form of informative diagrams, the results of daily geophagous activity by months are visualized. The main calculated 
indicators of the frequency of salt licking are given. The parameters of herd instinct were calculated. Based on the material, behavioral features of visiting salt licks that were not previously noted in the literature are described.

Until now, extraordinarily little attention has been paid to the study of geophagous activity and visiting mineral licks in the European part of Russia, although the creating of artificial salt licks has been used as a biotechnical measure for more than a century (Kulagin, 1932; Lvov, 1979). Artificial salt licks are auxiliary, and possibly the main sources of sodium for animals in areas where there is a deficiency of this element in water and feed. Author presume that artificial salt licks can be used as experimental sites for determining various population parameters (first of all, sex and age structure) of species visiting salt licks, as well as, in general, the species composition of mammals living in the nearby territory, parameters of its seasonal and interannual dynamics. Provided that methodologically reliable descriptions of habitat types, surrounding an organized mineral lick, are used, it becomes possible to accumulate primary data and analyze the relationships between population parameters with a specific biogeocenotical structure. With systematic collecting such information on artificial salt licks in different regions and different types of habitats, it can be successfully used to update paleoecological data on Pleistocene localities, for which the use as mineral licks are being reconstructed. The data are also relevant in the absence of a legal framework regulating the quantity and quality of the organization of artificial salt licks. Together with additional studies of the area of individual home ranges and behavioral characteristics of different age and sex groups of individuals, it is possible to create a new accounting method.

ACKNOWLEDGEMENTS. Author would like to express deep gratitude to the staff of the MOO "LOOiR", in particular Sinilnikov N.R., to the staff of the OO "VROOiR", in particular, Kokorin S.V. and Tofan E.P., for the provision of an experimental monitoring base and assistance in obtaining data from the observed objects, to the candidate of agricultural sciences, associate professor of the Saint-Peterburg State Forest Technical University named after S.M. Kirov Masaitis V.V. for support in the study of this topic, assistance in the development of primary methods for analyzing the information obtained and providing a significant part of the initial data. Author would like to express special gratitude to the graduate student of Peter the Great Saint-Petersburg Polytechnic University Vakulenko A.F. for consultations and development of scripts for the Qbasic64 and Matlab19R for specialized analysis of primary data. Author would also like to express deep gratitude to the author's supervisor, candidate of biological sciences Tikhonov A.N. for advice on writing and recommendations for the design of the article. Finally, special thanks to the doctor of biological sciences Boeskorov G.G. and the Anonymous Reviewer for valuable comments and practical advice on improving the text and structure of the article.

\section{References}

Ayotte J.B., Parker K.L. \& Gillingham M.P. 2008. Use of Natural Licks by Four Species of Ungulates in Northern British Columbia // Journal of Mammalogy. Vol.89. No.4. P.1041-1050.

Bjørneraas K., Herfindal I., Solberg E.J., Sæther B., van Moorter B. \& Rolandsen C.M. 2012. Habitat quality influences population distribution, individual space use and functional responses in habitat selection by a large herbivore // Oecologia. Vol.168. No.1. P.231-243.

Bobrowsky P.T., Mead J.I. \& Meltzer D.J. 1988. Environments and Extinctions: Man in Late Glacial North America // American Antiquity. Vol.53. No.2. P.427-428.

Boeskorov G.G. 2001. [Sistematics and Origin of modern Moose]. Novosibirsk: Nauka. 120 p. [in Russian].

Cederlund G. \& Okarma H. 1988. Home range and habitat use of adult female moose // Journal of Wildlife Management. Vol.52. No.2. P.336-343.

Cederlund G. \& Sand H. 1994. Home-Range size in relation to age and sex in moose // Journal of Mammalogy. Vol.75. No.4. P.1005-1012.

Committee for the Protection, Control and Regulation of the use of Fauna objects of the Leningrad region: website of the Government of the Leningrad region. 2021. Open data: https://fauna.lenobl.ru/ru/statistic/otkrytye-dannye/ (date of access: 15.02.2021) Updated date: 12.01.2021 [in Russian].

Danilkin A.A. 1999. [Deer (Cervidae). Mammals of Russia and adjacent regions.] Moscow. GEOS. 552 p. [in Russian].

Flueck W.T. \& Smith-Flueck J.A. 2008. Age-independent osteopathology in skeletons of a South American cervid, the Patagonian huemul (Hippocamelus bisulcus) // Journal of Wildlife Diseases. Vol.44. No.3. P.636-648.

Fraser D. \& Hristienko H. 1981. Activity of moose and white-tailed deer at mineral springs // Canadian Journal of Zoology. Vol.59. P.1991-2000.

Haynes G. 1985. On watering holes, mineral licks, death, and predation // Meltzer D. \& Mead J.I. (eds.). Environments and Extinctions in Late Glacial North America. Orono: Center for the Study of Early Man. P.53-71.

Hindelang M. \& Peterson R.O. 1996. Osteoporotic skull lesions in moose at Isle Royale National Park // Journal of Wildlife Diseases. Vol.32. No.1. P.105-108.

Jordan P.A., Botkin D.B., Dominski A.S., LowendorfH.S. \& Belovsky G.E. 1973. Sodium as a critical nutrient of the moose of Isle Royale // Proceedings of the "9th North American Moose Conference and Workshop" (Quebec, March 25-30). Quebec: Ontario Ministry of Natural Resources, Fish and Wildlife Research Branch and Wildlife Branch. P.1-28.

Knorre E.P. 1959. [Ecology of the Moose] // Trudy Pechoro-Ilychskogo gosudarstvennogo zapovednika. No.7. P.5-122. [in Russian]

Kulagin N.M. 1932. [Moose of the USSR]. Leningrad: Tipograhia Academii Nauk USSR. 120 p. [in Russian].

Lavelle M.J., Phillips G.E., Fischer J.W., Burke P.W., Seward N.W., Stahl R.S., Nichols T.A., Wunder B.A. \& VerCauteren K.C. 2014. Mineral licks: motivational factors for visitation and accompanying disease risk at communal use sites of elk and deer // Environmental Geochemistry and Health. Vol.36. No.6. P.1049-1061. 
Martynov E.N., Masaitis V.V. \& Gorokhovnikov A.V. 2011. [Hunting business. Hunting management and hunting economy: training manual]. Saint-Petersburg: Izdatelstvo Lan'. 448 p. [in Russian].

Leshchinskiy S.V., Zenin V.N., Orlova L.A. \& Burkanova E.M. 2010. [Animal salt licks of the Chulym-Yenisei plain mineral (geochemical) oases and centers of activity of mammoth fauna and Paleolithic man] // Vestnik Tomskogo Gosudarstvennogo Universiteta. No.333. P.181-186 [in Russian].

Leshchinskiy S.V. 2017. Strong evidence for dietary mineral imbalance as the cause of osteodystrophy in Late Glacial woolly mammoths at the Berelyokh site (Northern Yakutia, Russia) // Quaternary International. No.445. P.146-170.

Lvov I.A. 1979. [Salt licks] // Okhota i ohotnichie hozyaistvo. No.5. P.6-8. [in Russian]

Panchenko D., Serova L., Danilov P., Shakun V. \& Kozorez A. 2020. On the dynamics of the moose population in the Northern perifery of the range and in the ecological optimum zone // Principy èkologii. Vol.9. No.2. P.60-70 [in Russian].

Panichev A.M. 2011. [Lithophagy: geological, ecological and biomedical aspects]. Moscow: Pacific Institute of Geography, RAS. 149 p. [in Russian].

Risenhoover K.L. \& Peterson R.O. 1986. Mineral licks as a sodium source for Isle Royale moose // Oecologia. Vol.71. No.1. P.121-126.

Rea V.R., Hodder D.P. \& Child K.N. 2004. Considerations for natural mineral licks used by moose in land planning and development // Alces: A Journal Devoted to the Biology and Management of Moose. Vol.40. P.161-167.

Rea V.R., Hodder D.P. \& Child K.N. 2013. Year-round Activity Patterns of Moose (Alces alces) at a Natural Mineral Lick in North Central British Columbia, Canada // Canadian wildlife biology and management. Vol.2. No.1. P.36-41.

Sedikhin N.V. \& Masaitis V.V. 2018. [Visiting of mineral licks by moose (Alces alces L.) in spring-summer period on the territory of Leningrad region] // Izvestia SanktPeterburgskoj Lesotehniceskoj Akademii. No.222. P.50-65 [in Russian with English summary].

Sedikhin N.V. 2018. [Experience of using camera traps to detect individual features of moose (Alces alces L.) and population count] // Masaitis V.V. \& Nikolaeva M.A. (eds.). Proceedings of All-Russian Conference "The Anatoly Silantiev Memorial Readings, dedicated to the 150-th anniversary of the birth: Game management in Russia. History and modernity". Saint Petersburg (Russia): SaintPetersburg State Forest Technical University. P.87-90 [in Russian].
Sedikhin N.V. 2020. [Intravital, visually recognisable injuries of external organs and tissues of moose (Alces alces L.) as distinctive features of individuals] // Masaitis V.V. \& Nikolaeva M.A. (eds.). Proceedings of All-Russian Conference "The Anatoly Silantiev Memorial Readings, dedicated to the 150-thanniversary of the birth: Game management in Russia. History and modernity". Saint Petersburg (Russia): Saint-Petersburg State Forest Technical University. P.82-85 [in Russian].

Sennikov A.N. 2005. [Phytogeography of Northwest Russia (Leningrad, Pskov and Novgorod regions)] // Proceedings of Karelian Research Centre of RAS. No.7. P.206-243 [in Russian with English summary].

Stepanova V.V., Argunov A.V., Okhlopkov I.M. \& Kirillin R.A. 2016. [Lithophagial activity of moose (Alces alces L., 1758, Cervidae, Artiodactyla) in Central Yakutia] // Modern problems of science and education. No.6. P.544 [in Russian].

Stepanova V.V., Argunov A.V., Kirillin R.A. \& Okhlopkov I.M. 2017. Time-study of moose (Alces alces L., 1758) geophagia activity in the Central Yakutia // Russian Journal of Theriology. Vol.16. No.2. P.185-190.

Stepanova V.V., Tirsky D.I., Argunov A.V. \& Okhlopkov I.M. 2018. [Moose (Alces alces L., 1758, Cervidae, Artiodactyla) salt licking in South Yakutia] // Agrarnyi Vestnik Urala. No.7(174). P.52-57 [in Russian.]

Timmermann H.R. \& McNicol J.G. 1988. Moose habitat needs // The Forestry Chronicle. Vol.64. P.238-245.

Timofeeva E.K. 1974. [Moose (ecology, distribution, economic value)]. Leningrad: Izdatelstvo Leningradskogo Universiteta. 167 p. [in Russian].

Vereshchagin N.K. \& Rusakov O.S. 1979. [Ungulates of the North-West of the USSR (history, lifestyle and economic use)]. Leningrad: Nauka. 309 p. [in Russian].

Yudin A.A. \& Skumatov D.V. 2018. [The application of the moose census method by multiday resurvey of areas sampling present the inadequacy of the systemic basis of state wildlife monitoring // Collection of materials of the 6th international scientific and practical conference "Humanitarian aspects of hunting and hunting economy". Irkutsk: Fund for support of the development of the biosphere economy and the agricultural sector "Siberian Land Congress". P.13-36 [in Russian with English summary].

Zaitsev V.A. 2017. [Habitat areas and groups of moose (Alces alces)] // Lebedev A.V. (ed.). Scientific works of the state nature reserve "Kologrivsky forest". Sbornik nauchnih trudov Issue 1. Kologriv: State reserve "Kologrivsky forest”. P.113-122 [in Russian]. 